Прокопенко О. С.;

Рибидайло А. А., к.т.н., с.н.с.;

Турейчук А. М., к.т.н.;

Комолаєва Т. М.

Центр воєнно-стратегічних досліджень Національного університету оборони України імені Івана Черняховського, Київ

\title{
Варіант побудови рейтингу військовослужбовців на основі таксономічного аналізу
}

Резюме. Використовуючи методи таксономічного аналізу висвітлено порядок побудови рейтингового списку кандидатів для призначення на типову посаду.

Ключові слова: таксономія, факторний аналіз, рейтинг військовослужбовця, еталон ефективності.

Постановка проблеми. Основними вимогами керівництва держави та Міністерства оборони України у розбудові сучасних Збройних Сил України $\epsilon$ імплементація оборонної реформи. Одним із пріоритетних напрямів реформи є створення сучасної системи кадрового менеджменту, а саме, створення ефективної системи управління кар'єрою військовослужбовців, забезпечення прозорої та доброчесної системи добору, розстановки та призначення особового складу на посади [1].

Кадрові рішення щодо призначення військовослужбовців на посади і переміщення по службі здійснюються на підставі Резерву кандидатів для просування по службі. У Резерв зараховуються військовослужбовці, які за результатами оцінювання рекомендовані до просування по службі, а також, у разі службової необхідності чи відсутності кандидатів, i військовослужбовці, які за результатами діяльності оцінені із загальною оцінкою “добре” [2]. На підставі рекомендацій атестаційних комісій, результатів періодичного оцінювання та додаткових факторів визначається рейтинг кандидатів для просування по службі. Відбір та визначення рейтингу військовослужбовців здійснюється 3 метою якісного укомплектування посад військовослужбовців найбільш підготовленими фахівцями, здатними виконувати поставлені завдання на відповідних посадах. [3].

В умовах збройної агресії 3 боку Російської федерації, створення дієвого кадрового резерву Збройних Сил України набуває особливого значення. Отже, визначення рейтингу відібраних кандидатів $€$ нагальним завданням сьогодення. Оскільки, при цьому враховується чимала кількість характеристик кандидатів доцільно автоматизувати означений процес.

Аналіз останніх досліджень i публікацій. Як зазначив Міністр Оборони України, серед напрямів реформування Збройних Сил України є створення сучасної системи кадрового менеджменту: "Ми вже почали це робити, і вже $\epsilon$ резерв 3 офіцерівконтрактників, які брали участь у зоні АТО цей резерв складає дві тисячі осіб, яких ми просуваємо на вищі посади" [4]. У роботі М. П. Думенка [5] висвітлюються проблеми кадрового забезпечення, 3 якими зіткнулися кадрові органи у 2014-2015 рр. під час переходу на функціонування в умовах особливого періоду. У роботах О. В. Банчук-Петросової [6], О. В. Коваль [7], О. В. Устименка [8] також порушуються питання оцінювання ефективності та напрями удосконалення системи кадрового менеджменту, один 3 яких стосується прийняття кадрових рішень щодо призначення військовослужбовців на посади.

Завдання $з$ відбору найкращого кандидата на посаду $є$ досить складним процесом, який повинен враховувати ефективний метод відбору найкращого військовослужбовця серед багатьох критеріїв, які висуваються до кандидатів на певну посаду.

Для вирішення означеного завдання застосовуються методи статистичної обробки, багатовимірного порівняльного аналізу та інші, серед яких методи кластерного та таксономічного аналізу оцінки показників. Метод кластерного аналізу реалізований у програмному забезпеченні (ПЗ) "Рейтинг кандидата" [3]. Основна мета, яку вирішує метод кластерного аналізу є розбиття заданої вибірки об'єктів на групи, які називаються кластерами [9]. У кожному кластері знаходяться схожі за властивостями об'єкти у 
вибірці, але об'єкти різних кластерів між собою істотно відрізняються. У класичному розумінні метод кластерного аналізу не надає інтегральну оцінку кожному об'єкту дослідження, за допомогою яких можливо було б ранжувати ці об'єкти у списку від найвищого до найменшого. Цей метод дає змогу відібрати найвищі, найнижчі або середні показники у відповідні групи (кластери) [10].

Застосування таксономічного аналізу дає змогу оцінити кожен об'єкт дослідження окремо. Таксономічний аналіз як і кластерний набув широкого застосування в багатьох галузях науки - його використовують в археології, антропології, медицині, психології, хімії, біології, державному управлінні, філології, маркетингу, соціології та інших дисциплінах [11]. Основною перевагою методу є здатність усунути суб'єктивізм в оцінці об'єктів, що порівнюються. Використовуючи математичні способи ранжування та зважування ознак, таксономічний аналіз надає можливість 3 високою ймовірністю визначити схожість та відмінність об' єктів порівняння.

Застосування методів таксономічного аналізу для проведення досліджень в економічній сфері відобразилось у роботах таких вчених, як В. Плюта [10], О. Кожушка [12], В. І. Воробйова [13], Ю. А. Сгупова [14], Т. Б. Надтока [15] та інших. Але питання дослідження Застосування методів таксономічного аналізу при аналізі процесів кадрового менеджменту у відкритих джерелах авторами не знайдено.

Мета статті. Обгрунтування пропозицій щодо автоматизації процесів формування рейтингу військовослужбовців-кандидатів для призначення на типову посаду, 3 використанням методів таксономічного аналізу.

Виклад основного матеріалу. Принципи таксономії застосовуються в багатьох наукових галузях знань, для упорядкування об'єктів географіï, геології, мовознавства, етнографії та всього різноманіття органічного світу.

Довідка. Таксономія (від др. греч.

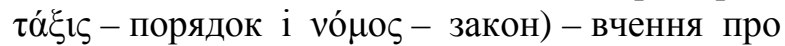
принципи класифікації та систематизації складноорганізованих сутностей , які ієрархічно співвідносяться між собою.

Задачу формування рейтингового списку кандидатів для призначення на визначену посаду можна подати у такому вигляді:
Вихідні дані:

- військовослужбовців - кандидатів на посаду можна описати множиною $M=\left(m_{1}, m_{2}, m_{3}, \ldots, m_{k}\right), \quad$ де $\quad k$-кількість кандидатів на посаду;

- кожний кандидат оцінений відповідно до методичних рекомендацій 3 порядку визначення рейтингу військовослужбовців Збройних Сил України [3] за відповідними критеріями $W=\left(w_{1}, w_{2}, w_{3}, \ldots, w_{n}\right), \quad$ де $n-$ кількість критеріїв оцінки.

Потрібно сформувати рейтинговий список кандидатів. Рейтинговий список- це список всіх кандидатів із зазначенням рейтингового бала та рейтингового місця кожного.

Використання таксономічного методу передбачає визначення таксономічної відстані відстань між точками багатовимірного простору (досліджуваними об'єктами кандидатами на посаду). Розмірність простору визначається числом ознак (критеріїв оцінювання). Обчислені відстані дають змогу визначити положення кожного досліджуваного об'єкта і робить можливим їх упорядкування за рейтингом.

Розв'язання поставленої задачі здійснюється послідовним виконанням певних операцій.

Вихідні дані можна представити у вигляді матриці спостережень:

$$
X=\left(\begin{array}{cccccc}
x_{11} & x_{12} & \ldots & x_{1 j} & \ldots & x_{1 n} \\
x_{21} & x_{22} & \ldots & x_{2 j} & \ldots & x_{2 n} \\
\ldots & \ldots & \ldots & \ldots & \ldots & \ldots \\
x_{i 1} & x_{i 2} & \ldots & x_{i j} & \ldots & x_{i n} \\
\ldots & \ldots & \ldots & \ldots & \ldots & \ldots \\
x_{k 1} & x_{k 2} & \ldots & x_{k j} & \ldots & x_{k n}
\end{array}\right),
$$

де $k$-кількість військовослужбовців $n$ вимірного простору, яке дорівнює числу строк матриці;

$n$-число критеріїв оцінювання, яке дорівнює числу стовбців матриці;

$x_{i j}-$ значення критерію оцінювання $j$, для військовослужбовця $i$.

Ознаки у матриці (1) описують різні якості критеріїв оцінювання, мають різні шкалі оцінювання та між собою їх порівняти неможливо [16]. Для стандартизації цих показників необхідно привести показники матриці до відцентрованих безрозмірних значень $Z_{i j}$ : 


$$
z_{i j}=\frac{x_{i j}-\overline{x_{j}}}{\sigma_{j}},
$$

де $\quad \overline{x_{j}}=\frac{1}{k} \sum_{i=1}^{k} x_{i j}-$ середнє арифметичне значення ознаки $j$;

$$
\sigma_{i}=\sqrt{1 / k \sum_{i=1}^{k}\left(x_{i j}-\overline{x_{j}}\right)^{2}}-\text { середньо квадрати- }
$$

чне відхилення ознаки $j$.

У результаті перетворень, матриця (1) виглядатиме:

$$
X=\left(\begin{array}{cccccc}
z_{11} & z_{12} & \ldots & z_{1 j} & \ldots & z_{1 n} \\
z_{21} & z_{22} & \ldots & z_{2 j} & \ldots & z_{2 n} \\
\ldots & \ldots & \ldots & \ldots & \ldots & \ldots \\
z_{i 1} & z_{i 2} & \ldots & z_{i j} & \ldots & z_{i n} \\
\ldots & \ldots & \ldots & \ldots & \ldots & \ldots \\
z_{k 1} & z_{k 2} & \ldots & z_{k j} & \ldots & z_{k n}
\end{array}\right) .
$$

Наступним кроком аналізу є розрахунок відстані між кожним елементом $z_{i j}$ iз сукупності усіх ознак матриці (3), які досліджуються. Для цього розрахунку $\epsilon$ декілька методів: за допомогою метрики Чебишева, Евклідової метрики або методу відстаней Хеммінга [17]. У статті використано Евклідову відстань, унаслідок чого матриця (3) перетворюється у вигляд матриці $D$, розмірність якої $k \times k$ :

$$
\begin{aligned}
D & =\left(\begin{array}{ccccc}
0 & d_{12} & d_{1 a} & \ldots & d_{1 k} \\
d_{21} & 0 & d_{2 a} & \ldots & d_{2 k} \\
\ldots & \ldots & \ldots & \ldots & \ldots \\
d_{i 1} & d_{i 2} & 0 & \ldots & d_{i k} \\
\ldots & \ldots & \ldots & \ldots & \ldots \\
d_{k 1} & d_{k 2} & d_{k a} & \ldots & 0
\end{array}\right), \quad \text { (4) } \\
\text { де } d_{i a}=\sqrt{1 / n \sum_{j=1}^{k}\left(z_{i j}-z_{a j}\right)^{2}} & \text { - відстань між } i \text {-м }
\end{aligned}
$$
та $a$-м рядком матриці (3)

Зазначимо, що $a$-й рядок для матриці (3) $\epsilon$ набором показників іншого військовослужбовця i, таким чином, матриця (4) показує наскільки віддалені між собою загальні стандартизовані показники за всіма критеріями оцінювання між кожним військовослужбовцем. Тобто відстань від військовослужбовця у $i$-му рядку матриці (4) до кожного іншого військовослужбовця буде у значенні $a$-го стовпця матриці, відповідно, якщо $i=a-$ значення показника дорівнює нулю.
Стандартизація показників є необхідною процедурою таксономічного аналізу - обумовлює однаковий вплив на всі об'єкти, які досліджуються. У процесі стандартизації виникає вирівнювання дисперсій, а математичне очікування усіх показників дорівнює нулю. Тому, для того, щоб позбутися нівелювання даних, необхідно встановлювати вагові коефіцієнти показників. Процедура розрахунку вагових коефіцієнтів починається 3 визначення критичних відстаней між показниками військовослужбовців та визначення екстремуму: $\varepsilon=\frac{\max }{i} \frac{\min }{a} d_{i a}$ - максимальне серед мінімальних $i$-х значень відстані $d, a$-го стовпця матриці (4).

Далі розраховується сума відстаней по кожному об'єкту, при яких значення кожного 3 об' єктів не перевищувало б значення критичної відстані $Q_{i}=\left\{i, a \mid d_{i a} \leq \varepsilon ; i=\overline{1, k}\right\}$ :

$$
\omega_{i}=\sum_{i, a \in q_{i}}^{i} d_{i a}(5) \text {. }
$$

Вагові коефіцієнти для військовослужбовців розраховуються за формулою $\lambda_{i}=\omega_{i} / \omega_{m}$, де $\omega_{m}$ - максимальне значення $\omega_{i}$.

Критерії, які використовуються як додаткові фактори визначення рейтингу військовослужбовців, можуть мати стимулюючий та дестимулюючий вплив. Критерії, які здійснюють стимулюючий вплив, характеризуючи його у кращий бік утворюють множину $K_{s}$, відповідно дестимулюючий вплив - множину $K_{d}$.

Наступним етапом $є$ розрахунок відстані $C_{i 0}$ від кожного $i$-го елементу матриці (3) до точки еталону ефективності $P_{0} 3$ урахуванням вагових коефіцієнтів $\lambda_{i}$.

$$
C_{i 0}=\sqrt{\sum_{j=1}^{n}\left(z_{i j}-z_{a j}\right)^{2}}
$$

Еталон ефективності $P_{0}$ визначається на підставі стимулюючого та дестимулюючого впливу кожного з критеріїв оцінювання [13]:

$$
P_{0}=\left(Z_{01}, Z_{02}, \ldots, Z_{0 j}, \ldots, Z_{0 n}\right),
$$

де $Z_{0 s}=\max Z_{r s}, n p u \mathrm{~s} \in \mathrm{K}_{\mathrm{s}}$;

$$
Z_{0 s}=\min Z_{r s}, n p u \mathrm{~s} \in \mathrm{K}_{\mathrm{d}} \text {. }
$$


Таксономічний показник рейтингу кожного 3 військовослужбовців (інтегральна оцінка) розраховується таким чином [10]:

(7),

$$
R_{i}=1-C_{i 0} / C_{0}
$$

де $C_{0}=\overline{C_{0}}+2 \sigma_{0}$ - коефіцієнт таксономії;

$$
\overline{C_{0}}=1 / k \sum_{i=1}^{k} C_{i 0} \text { - математичне сподіван- }
$$

ня відстаней до еталону ефективності $P_{0}$;

$$
\sigma_{0}=\sqrt{1 / k \sum_{i=1}^{k}\left(C_{i 0}-\overline{C_{0}}\right)^{2}} \text { - середнє квад- }
$$

ратичне відхилення.

Вищенаведений порядок формування рейтингового списку кандидатів на типову посаду можна інтерпретувати як проектування точок багатовимірного простору на пряму.

Інтегральна оцінка $R_{i}$ синтетично характеризує зміни значень показника рейтингу військовослужбовця. Цей показник можна інтерпретувати так: чим вище його значення, тим вище рейтинг $i$-го військовослужбовця. Також він приймає:

- більші значення при високих показниках критеріїв-стимуляторів та менших значеннях критеріїв-дестимуляторів;

- менші значення при низьких показниках критеріїв-стимуляторів та більших значеннях критеріїв-дестимуляторів.

Метод таксономії реалізовано в діючому макеті визначення рейтингу військовослужбовців за допомогою програмного забезпечення СУБД Microsoft Access. Використання програмної середи розробки Visual Basic for Applications дало змогу:

- формувати рейтингові списки військовослужбовців для призначення на типову посаду, які за результатами щорічного оцінювання рекомендуються у Резерв на вищу посаду;

\section{- формувати}

рейтинг військовослужбовців за інтегральною оцінкою, яка розраховується на підставі додаткових критеріїв оцінювання;

- формувати регламентовані звітні форми згідно керівних документів [3].

Висновки. Таким чином, застосування методу таксономії у сфері управління кар'єрою персоналу дасть змогу вирішити питання, пов'язані 3 точністю та обгрунтованістю багатовимірних оцінок персоналу. Універсальність цього методу полягає в спроможності статистичного багатовимірного аналізу якостей, кваліфікацій, оцінки діяльності персоналу та їх порівняння між об' єктами дослідження.

Реалізація методу таксономії для визначення рейтингу військовослужбовців щодо призначення на посади в автоматизованих системах управління персоналом на прикладі розробленого макету, дасть змогу підвищити оперативність та прозорість у прийнятті кадрових рішень, а склад макету дасть змогу розробнику усвідомити та впровадити у діяльність органів кадрового менеджменту.

\section{СПИСОК ВИКОРИСТАНОЇ ЛІТЕРАТУРИ}

1. Указ Президента України від 20.05.2016 № 240/2016 про рішення Ради національної безпеки i оборони України "Про Стратегічний оборонний бюлетень України”.

2. Наказ Міністра оборони України від 10.04.2009 №170 “Про затвердження Інструкції про організацію виконання Положення про проходження громадянами України військової служби у Збройних Силах України" (зі змінами).

3. Методичні рекомендації 3 порядку визначення рейтингу військовослужбовців Збройних Сил України, затверджені директором Департаменту кадрової політики Міністерства оборони України від 29.12.2009 № 226/1/4545.

4. Виступ Міністра оборони України Полторака С. Т. [електронний ресурс]./ режим доступу: https://www.unian.ua/politics/1284916poltorak-predstaviv-u-shtab-kvartiri-nato-planreformuvannya-zbroynih-sil-ukrajini-do-2020roku.html.

5. Думенко М.П. Аналіз функціонування системи кадрового забезпечення під час дії особливого періоду у 2014-2015 роках. - К, 2016, ISSN 23117249. - Сучасні інформаційні технології у сфері безпеки та оборони № 2 (26) 2016 р.

6. Банчук-Петросова О.В. Потреба в удосконаленні кадрової політики в секторі безпеки України в сучасних умовах. - 2015, ISSN 1813-3401. Держава та регіони. Серія: Державне управління №2 (50) 2015p.

7. Коваль О.В. Кадровий менеджмент на сучасному етапі реформування та розвитку Збройних Сил України. - 2012, Теорія та практика державного управління №4 (39) 2012 р.

8. Устименко О. Оцінка ефективності системи кадрового менеджменту в Збройних Силах України. - 2010, Вісник Національної академії державного управління при Президентові України. - № 32010 p.

9. Кластерний аналіз. Матеріал 3 Вікіпедії. [електронний ресурс]./ режим доступу: https://uk.wikipedia.org/wiki/Кластерний_аналіз.

10. Плюта В. Сравнительный многомерный анализ в экономических исследованиях / В. Плюта; пер. с польск. - М. Финансы и статистика, 1989 р. 
11. Таксономія. Матеріал з Вікіпедії. [електронний pecypc]./ режим доступу: https://uk.wikipedia.org/wiki /Таксономія.

12. Кожушко О. Використання методу таксономії для оцінки рівня захисту інтелектуального капіталу промислових підприємств. . - 2010 , ISSN 1993-0259. ISSN 2219-4649. Економічний аналіз №7 2010 р.

13. Воробьев В.И. Таксономический показатель уровня эффективности применения частей и подразделений внутренних войск МВД Украины
/ Городнов В.П., Фык О.В. - 2003, ISSN 1681-7710. Системи обробки інформації, №5 2003 р.

14. Егупов Ю. А. Повышение корректности многомерных оценок в процессе формирования производственной программы предприятия. - О., 2009, Одеський національний економічний університет. Економічні інновації №38 2009 р.

15. Надтока Т.Б. Многомерное оценивание уровня социально-экономического развития предприятия / Виноградов А. Г. - Х., 2014, Науковий журнал “Бізнес інформ” №1 (432) 2014 р.

Стаття надійшла до редакції 03.11.2017

\section{Прокопенко А. С.;}

Рыбыдайло А. А., к.т.н., с.н.с.;

Турейчук А. Н., к.т.н.;

Комолаєва Т. Н.

Центр военно-стратегических исследований Национального университета обороны Украины имени Ивана Черняховского, Киев

\section{Вариант построения рейтинга военнослужащих на основе таксономического анализа \\ Резюме. Используя методы таксономического анализа, представлен порядок построения рейтингового списка кандидатов для назначения на типовую должность. \\ Ключевые слова: таксономия, факторный анализ, рейтинг военнослужащего, эталон эффективности.}

\section{A. Prokopenko;}

\section{A. Rybydajlo, Ph.D, senior researcher;}

A. Tureychuk, Ph.D;

T. Komolaeva

Center for Military and Strategic Studies of the National Defence University of Ukraine named after Ivan Chernyhovsky, Kyiv

\section{The variant of ranking the military personnel on the basis of taxonomic analysis}

Resume. Using the methods of taxonomic analysis, the procedure for constructing the rating list of candidates for appointment to a standard position is presented.

Keywords: taxonomy, factor analysis, military officer rating, efficiency benchmark. 